\title{
Sustainable Rural Livelihood Security of Small Farmers through Efficient Resource Recycling in Crop-Fish-Poultry-Mushroom based Integrated Farming System Model
}

\author{
Hemanta Kumar Sahoo ${ }^{1 *}$, Basudev Behera ${ }^{2}$, Manoranjan Satapathy ${ }^{2}$ \\ and Stuti Debapriya Behera ${ }^{2}$ \\ ${ }^{1}$ Directorate of Extension Education, ${ }^{2}$ Department of Agronomy, \\ OUAT, Bhubaneswar -751 003, India \\ *Corresponding author
}

\section{A B S T R A C T}

\section{Keywords}

Rainfed rice farms,

Conventional cropping system, Productivity, Profitability

\section{Article Info}

Accepted: 15 November 2019 Available Online: 10 December 2019
A study was undertaken under rainfed conditions to develop pond-based IFS models for smallholder farm of 1.6 ha comprising rice-onion cropping system, multilayer pisciculture, poultry and mushroom with conventional rice-green gram cropping system. Field experiments were conducted at five cluster of villages located in five different blocks viz. Khajuripada of Kandhamal district, Dhenkanal Sadar and Odapada of Dhenkanal district, Golamunda and Narla of Kalahandi district of Odisha under rainfed medium land situations during 2010-11 to 2012-13. The IFS model gave rice equivalent yield (REY) of $28081 \mathrm{~kg} / \mathrm{ha}$, net return of ₹ $1,42,201 / \mathrm{ha}$ and B : C of 1.82 as compared to REY of 4188 $\mathrm{kg} / \mathrm{ha}$, net return of $₹ 9522 / \mathrm{ha}$ and $\mathrm{B}: \mathrm{C}$ of 1.25 in conventional rice-greengram cropping system. Among the clusters, Narla cluster recorded the maximum REY of $17,119 \mathrm{~kg} / \mathrm{ha}$ closely followed by Dhenkanal Sadar with REY of $17,038 \mathrm{~kg} / \mathrm{ha}$. The 1.6 ha IFS model provided $5461 \mathrm{~kg}$ grain of rice, $29,811 \mathrm{~kg}$ of onion, $443.6 \mathrm{~kg}$ fish, $1983.0 \mathrm{~kg}$ raw fruit yield of papaya, $1083.0 \mathrm{~kg}$ fruit yield of plantain, $642.0 \mathrm{~kg}$ drumstick, $847.0 \mathrm{~kg}$ poultry meat, $901.2 \mathrm{~kg}$ paddy straw mushroom and $714.4 \mathrm{~kg}$ oyster mushroom to the farm family and recyclable by-products of $5940 \mathrm{~kg}$ paddy straw, $5000 \mathrm{~kg}$ pond silt, $2104.0 \mathrm{~kg}$ poultry excreta and $13022 \mathrm{~kg}$ mushroom spent for recycling in the system and use as inputs by other enterprises in the models. The 1.6 ha rainfed farm with conventional cropping provided $4290 \mathrm{~kg}$ grain of rice and $750 \mathrm{~kg}$ of green gram for consumption by the farm family. The Sustainable Yield Index (SYI) and Sustainable Value Index (SVI) values were 0.82 and 0.44 , respectively, in pond based IFS model as compared to 0.13 and 0.03 in conventional cropping system of rice-green gram sequence cropping under rainfed conditions.

\section{Introduction}

The average holding of a farm in India has been declining over the years and out of 138 million operational holdings, over 93 million are below the size of one hectare (MoA, GOI. 2015). A steady increase in population, construction of residential complexes, mining, 
industrialization and urbanization have led to the decline in per capita availability of land in India leaving hardly any scope for horizontal expansion of this resource to produce food. The ultimate way of sustaining the food production is vertical approach aiming at increased total production per unit area and time. This productivity enhancement is possible by the holistic integration of different on and off-farm enterprises. In Odisha, about $20 \%$ farmers are small with average holding of 1.63 ha (DA \& FP, Odisha. 2014). The rice based cropping systems are predominant in the state. Average land holding and present level of productivity from rice based cropping systems cannot sustain a 6-member farm family in the state. Besides, a decline in the crop productivity has led to food and nutritional insecurity. The livelihood conditions of rural farmers are good. In different rice growing ecologies, productivity has been declining due to several bio-physical, edaphological, socio-economic, technological and institutional constraints. Productivity of the crop fluctuates from year to year due to several climatic constraints viz., high variability in commencement and cessation of south-west monsoon, erratic spatial and temporal distribution of rainfall, prolonged dry spells and drought and high intensity rainfall and flood. Rice performs well in a saturated soil environment, but it is subjected to stress from both deficit and excess moisture in various ecologies. There are several drawbacks in single enterprise approach. Still monocropping of rice is prevalent in the rainfed belt of the state. Land is kept fallow after rice or occasionally short duration pulses are grown as sequence crops on residual moisture.

Construction of on-farm water harvesting ponds amounting to $10 \%$ of medium and low land will be helpful in storing surplus precipitation. These ponds will facilitate diversification of small rainfed rice farms in the state and ensure livelihood security of small farmers.
The integration of allied enterprises with crop components in a limited scale on a farm basis has a bright future owing to a great market for their outputs. Further, some of the by-products of these enterprises serve as valuable manure for recycling to the crop component within the system. In this system, waste materials are effectively utilized by linking complementary components and thus utilizing the byproducts as organic manures, which will ultimately improve the fertility status of the soil by averting pollution. The recycling of produce/waste material of anyone of the components as input on the other component linked in the farming system could reduce the cost of production which enables to increase the net income of the farm as a whole. Thus, energy obtained from an IFS in various forms is much higher than energy input, as the by-products /wastes of these allied enterprises provide all the raw material and energy required for the food chain in another system. These complementarities when carefully chosen, keeping in view the soil and environmental conditions, usher in greater dividends (Rangasamy, 1999). This approach helps the marginal farmers to improve their standard of living by providing sufficient employment and money flow.

Harvest of surplus rainwater during rainy season enhances opportunity for diversification in space and time dimension. Water productivity is enhanced by about one to two times due to multiple use of pond water compared to farmers' practice of rainfed crop (Das et al., 2013). Ghosh et al., (2009) observed enhancement in cropping intensity, employment generation and farm income due to rainwater harvesting and its efficient recycling in farm ponds. Farming system approach should be adopted to meet the demand to mitigate risks and uncertainties, achieve higher food production and better standard of living (Govindan et al., 1990). The present investigation was undertaken to maximize the profitability of small farm of 
size 1.6 ha in 5 clusters of three different agroclimatic zones of Mid Central Table Land Zone, North Eastern Ghat Zone and Western Undulating Zone of Odisha through farming system approach.

\section{Materials and Methods}

\section{Experimental details}

The present investigation was carried out for three consecutive years from April 2010 to March 2013 in smallholder farm of size of 1.6 ha. Two sources of water i.e. no pond/rainfed and pond/irrigated were tried with five replications(clusters) located in five different blocks viz. Khajuripada $\left(84^{\circ} 24^{\prime}\right.$ E Longitude, $20^{\circ} 26^{\prime} \mathrm{N}$ Latitude and $476 \mathrm{~m}$ above mean sea level(AMSL) of Kandhamal district(North Eastern Ghat Zone), Dhenkanal Sadar $\left(85^{\circ} 38^{\prime}\right.$ E Longitude, $20^{\circ} 40^{\prime} \mathrm{N}$ Latitude and $56 \mathrm{~m}$ AMSL) and Odapada ( $85^{\circ} 26^{\prime}$ E Longitude, $20^{\circ} 45^{\prime} \mathrm{N}$ Latitude and $56 \mathrm{~m}$ AMSL) of Dhenkanal district (Mid Central Table Land Zone), Golamunda ( $83^{\circ} 01^{\prime}$ E Longitude, $19^{\circ} 49^{\prime}$ $\mathrm{N}$ Latitude and $254 \mathrm{~m}$ AMSL)and Narla $\left(83^{\circ} 22^{\prime}\right.$ E Longitude, $20^{\circ} 03^{\prime} \mathrm{N}$ Latitude and $254 \mathrm{~m}$ AMSL) of Kalahandi district(Western Undulating Zone) of Odisha in rainfed farm size of 0.8 ha (marginal) under shallow submerged low land situations.

The objective of the study was to compare the performance of the pond based Integrated Farming System (IFS) model comprising riceonion cropping system, pisciculture + on dyke plantation, poultry and mushroom with rainfed rice. The soils of Khajuripada were sandy clay loam in texture and mostly acidic in reaction.

The soils of Dhenkanal Sadar and Odapada were clay loam in texture with slightly acidic to slightly alkaline in soil reaction. The soils of Golamunda and Narla were heavy textured with textural class of clay and slightly acidic to slightly alkaline in reaction.
The components of IFS were selected based on the popularity and suitability to rainfed rice lands in Odisha. Farm ponds were excavated to (i) provide assured irrigation to rice crop in kharif season during dry spell, (ii) take up a second profitable crop of onion during rabi season after the harvest of rice crop and (iii) practice multilayer pisciculture. Pond dyke was used for planting of papaya, banana and drumstick to provide raw fruits for culinary purpose.

Dug well was excavated in the area of IFS model to meet the water requirement of household, poultry and mushroom enterprises and to meet the water need of pisciculture component during shortage of water in the pond. In all the IFS models, rice cv. 'Lalat' $(125-130 \mathrm{~d})$ and onion cv. 'N-53'(90-100 d after transplanting) were selected for the study due to yield stability. Under rainfed condition without pond, rice (Lalat) - green gram (Local) cropping system was followed, except Khajuripada cluster where rice- fallow was followed. In IFS models, cropping area was $1.431 \mathrm{ha}$, whereas under no pond situation, the cropping area was 1.6 ha.

The rice seeds@ @75 kg/ha was sown in the nursery during $1^{\text {st }}$ week of June both in IFS models and conventional system and transplanted during $1^{\text {st }}$ week of July. During the $1^{\text {st }}$ year, FYM was applied @ 5 t/ha in all IFS models along with recommended fertilizer. During the $2^{\text {nd }}$ year and the $3^{\text {rd }}$ year; FYM, recommended fertilizers along with byproducts of onion, poultry litter along with poultry droppings, tank silt and composted mushroom spent substrate were used in the paddy field. In conventional rice, only chemical fertilizer was applied. Chemical fertilizers @ NPK $80-40-40 \mathrm{~kg} / \mathrm{ha}$ were applied in form of DAP, Urea and MOP. Chemical fertilizer was applied in three splits i.e. $25 \% \mathrm{~N}$, full $\mathrm{P}$ and $50 \% \mathrm{~K}$ as basal, $50 \% \mathrm{~N}$ at tillering and $25 \% \mathrm{~N}$ and $50 \% \mathrm{~K}$ at panicle initiation stage. The crop 
was harvested during $3^{\text {rd }}$ week of October. Onion seeds @ $10 \mathrm{~kg} / \mathrm{ha}$ was used for raising nursery during $2^{\text {nd }}$ week of November. The seedlings of 45 days old were planted in the main field at a spacing of $15 \mathrm{~cm}$ x10 cm during the last week of December. The fertilizer dose of 150- 50-80-50 kg NPKS/ha was applied in three splits i.e. all $\mathrm{P}, \mathrm{K}$ and $\mathrm{S}$ with $50 \% \mathrm{~N}$ as basal and rest $50 \% \mathrm{~N}$ in two equal splits at 30 and 45 days after transplanting. The crop was harvested during $1^{\text {st }}$ week of April.

Greengram crop (Local var. Jhain/Suni) was sown@25 kg/ha under conventional system during the $2^{\text {nd }}$ week of November and harvested during the last week of January. The chemical fertilizer @ NPK 10-20-0 kg/ha was applied at basal.

Ten percent of area of the farm i.e. 0.16 ha was diverted for farm pond. The ponds were rectangular in shape having an average water depth of $1.45 \mathrm{~m}$. Fingerlings of catla (Catla catla L.), rohu (Labeo rohita L.), and mrigal (Cirrhinus mrigala L.) numbering 240, 320 and 240, respectively, were released to the ponds every year in the month of August. The poultry droppings was applied every day morning@ @ $40 \mathrm{~kg} / \mathrm{ha}$ as feeding material for the growth of fingerlings in the pond (Kumar and Ayyapan, 1998).

Papaya (Red Lady variety) seedlings were planted in the pond dyke at a linear distance of $2.0 \mathrm{~m}$ in the middle of the dyke. All total 80 plants were planted in the dyke of the pond. Banana (Bantal variety) plants numbering 76 were planted in the inner side of the pond dyke at a linear distance of $2.1 \mathrm{~m}$. Drumstick (PKM-1 variety) seedlings numbering 64 were planted in the outer side of the pond dyke at a linear distance of $2.5 \mathrm{~m}$. Poultry units of size $4.5 \mathrm{~m}$ x $3.0 \mathrm{~m}$ (15'x10') were constructed for rearing five batches @ 100 broiler birds per batch in a year. One-day old chicks numbering 100 of improved breed 'Vencobb' were reared with recommended feeding, health care and management.

Mushroom cultivation was taken as a supplementary enterprise in the IFS models to utilize paddy straw efficiently. Mushroom shed of size $7.5 \mathrm{~m} \times 3.6 \mathrm{~m}$ (25'x12') with three-tier arrangement was constructed for raising mushroom. A total of 120 beds of paddy straw mushroom (Volvariella volvacea)/ month for 8 batches during March to October and 225 bags of oyster mushroom (Pleurotus sajar-caju)/ two months for 2 batches during November to February were raised. Since diversified enterprises were taken in the study, the yield of each enterprise was converted to rice equivalent yield. Studies on economics of production were made by keeping a record on number of labourers engaged, power and input utilized.

The straw available after processing of paddy was weighed and kept for utilization in mushroom production. Round the year mushroom cultivation required higher quantity of straw than the actual straw yield in the farming system model. The extra straw was purchased from other farmers of the locality for mushroom production as sufficient straw was available in the locality. The mushroom spent substrates were utilized for compost making which was utilized in the crop components. Poultry excreta of 100 birds along with the litter materials were collected after one cycle of 6 weeks and weighed. Poultry excreta were utilized in the fish pond as fish feed and the remaining excreta was utilized as manure in the cropping enterprise. After the harvest of fish during the month of April, the fish pond was dried and pond silt was collected. The pond silt after the $1^{\text {st }}$ and $2^{\text {nd }}$ year was weighed and utilized in the cropping enterprise as compost.

Soil samples of the experimental sites were collected before start of the experiment and 
after completion of the experiment. Composite soil samples were collected at $15 \mathrm{~cm}$ depth, dried under shade and analyzed for physical and chemical properties of soil as per standard procedures(Piper, 1950). The data collected were statistically analyzed following procedure for randomized block design (Gomez and Gomez, 1984).

\section{Results and Discussion}

\section{Productivity of crops in different clusters}

During 2010-11, the rice grain yield was lower in the Integrated Farming System (IFS) model farm ant it increased significantly during 2011-12 and 2012-13 (Table 1). The rice yield was significantly lower during 2011-12 under rainfed condition compared to 2010-11 and 2012-13. In the rainfed rice farm, the growth and yield of rice was affected due to dry spell during $30^{\text {th }}$ SMW ranging from 30 July to 5 August coinciding with tillering stage and $40^{\text {th }}$ and $41^{\text {st }}$ SMW ranging from 01 October to 14 October coinciding with grain filling stage. Being a shallow rooted crop, rice was highly susceptible to drought and supplemental irrigation through pond favored growth and development and attained higher yield. Significantly lower grain yield of rice was observed in Khajuripada cluster of villages under both IFS model and rainfed farms. This was due to the prevalence of eroded soil with sandy clay loam texture (Table 9) and lower water holding capacity. All other cluster of villages attained significantly higher grain yield compared to Khajuripada cluster. Narla cluster attained the maximum yield of 4382 $\mathrm{kg} / \mathrm{ha}$ due to the presence of moisture retentive vertisol with higher clay content. Khajuripada cluster attained rice yield of $3166 \mathrm{~kg} / \mathrm{ha}$ under IFS model. Khajuripada, Dhenkanal Sadar, Odapada and Golamunda recorded 27.7, 7.6, 12.3 and $16.6 \%$ less grain yield compared to Narla cluster. The mean rice yield in rainfed farm was $2681 \mathrm{~kg} / \mathrm{ha}$. Conversion of rainfed rice farm to pond based IFS model enhanced the rice grain yield by $42.3 \%$ due to provision of life saving irrigation during the period of dry spell under pond based model.

Islam and Mandal (1992) found that one supplemental irrigation of $6 \mathrm{~cm}$ to rainfed rice increased the rice yield by $59 \%$. A pond size of about $5 \%$ of the total cultivable land was estimated to store sufficient water for providing the supplemental irrigation. Khajuripada cluster of villages attained the lowest straw yield of rice under both IFS model and rainfed farm, while Narla cluster attained significantly higher straw yield. Narla cluster attained the maximum mean straw yield of $4801 \mathrm{~kg} / \mathrm{ha}$ under the IFS model over years. The mean straw yield under the IFS model was $4151 \mathrm{~kg} / \mathrm{ha}$ and it was $37.2 \%$ more than the rainfed rice farm. Onion bulb yield was significantly lower in 2010-11 and it was significantly higher in 2011-12 and 2012-13. Maximum onion bulb yield of $21125 \mathrm{~kg} / \mathrm{ha}$ was attained in 2012-13.

Among the clusters, Narla cluster ranked the first. Golamunda, Dhenkanal Sadar, Odapada and Khajuripada clusters were ranked the second, the third, the fourth and the fifth, respectively for onion yield. Khajuripada cluster attained the minimum onion bulb yield of $18791 \mathrm{~kg} / \mathrm{ha}$ due to prevalence of low moisture retentive sandy clay loam soil. Dhenkanal Sadar and Odapada clusters in Dhenkanal district attained significantly higher bulb yield of 20482 and $20161 \mathrm{~kg} / \mathrm{ha}$, respectively. The IFS models in Golamunda and Narla clusters gave significantly higher onion bulb yield of 22243 and $22481 \mathrm{~kg} / \mathrm{ha}$ amounting to an increase of 18.3 and $19.6 \%$ over Khajuripada cluster. This was due to the existence of vertisol with high moisture retention capacity. Onion is a shallow rooted crop with bulbs and roots situated within $3 \mathrm{~cm}$ of top soil. In a heavy soil, the retention of moisture following irrigation would last for a 
longer period. The bulb development during 60-70 days stage of the crop would depend on the presence of sufficient soil moisture. In a light textured soil, leaching and percolation would be rapid following irrigation, and accordingly bulb development would be affected due to insufficient soil moisture.

The green gram crop was taken up in four clusters viz., Dhenkanal Sadar, Odapada, Golamunda and Narla under residual moisture condition. The crop could not be taken in Khajuripada cluster due to low water holding capacity of the soil and cattle menace. The farmers took traditional 'Suni' or 'Jhain' moong depending on the moisture status of soil at the time of harvest of rice. 'Suni' moong is generally raised if rain ceases early in the rainy season and 'Jhain' is taken if rainy season is prolonged and the crop is sown late after soil conditions become congenial for tillage operations. The yield of green gram was the maximum of $494 \mathrm{~kg} / \mathrm{ha}$ during 201011 which was at par with 2012-13. The minimum green gram yield of $438 \mathrm{~kg} / \mathrm{ha}$ was attained in 2011-12. Dhenkanal Sadar ranked the first with respect to green gram yield which was significantly higher than other clusters. Odapada, Narla and Golamunda clusters were ranked the second, the third and the fourth with respect to green gram yield. Dhenkanal Sadar cluster of villages attained significantly higher yield of $538 \mathrm{~kg} / \mathrm{ha}$ due to the presence of loamy soil with higher moisture retention and good aeration. The yield declined by $11.6,16.3$ and $25.6 \%$ in Odapada, Narla and Golamunda clusters respectively.

\section{Productivity of non-crop enterprises}

There was a significant variation in the fish yield in different years. The total fish yield was the maximum during 2010-11, followed by 2012-13 and 2011-12 (Table 2). Golamunda cluster attained the minimum fish yield due to early capture of fish in March due to drying of pond. In Golamunda cluster, the water level declined faster due to low rainfall and early withdrawal of monsoon than that of Narla cluster.

The mean fish production ranged from 2634 $\mathrm{kg} / \mathrm{ha}$ in Golamunda cluster to $2884 \mathrm{~kg} / \mathrm{ha}$ in Dhenkanal Sadar cluster over years. The maximum fish yield in Dhenkanal Sadar cluster was due to higher length and weight of individual fish species. Singh et al., (2004) reported higher level of fish production through recycling of poultry manure owing to better plankton development and direct feeding to fishes. The low fish yield in Khajuripada cluster was due to early drying of pond and extremely low atmospheric temperature during November to February. Yashouv (1963) reported low growth rate of catla, rohu and mrigal fish species during November to March due to low water temperature in those months. April to October, when the water temperature ranges from $28.0^{\circ}$ to $34.8^{\circ} \mathrm{C}$ at noon time, usually would be the best period for fish growth.

Papaya, banana and drumstick were taken up as on-dyke plantation. Banana was taken up in the lower part of inner slope, while papaya was taken up in the upper part of inner slope and drumstick was taken up in the outer side of the pond embankment. Das et al., (2013) successfully demonstrated fruits like banana, citrus, guava and papaya in the pond dykes/ banks in the farmers' field in Meghalaya.

The productivity of papaya was comparatively higher in 2011-12 and the productivity declined thereafter. Among different clusters, Dhenkanal Sadar attained the maximum fruit yield of $71094 \mathrm{~kg} / \mathrm{ha}$ from 1.6 ha IFS model. Odapada cluster ranked the $2^{\text {nd }}$ in papaya productivity. Golamunda cluster gave the lowest fruit yield under IFS model. The higher yield in Dhenkanal Sadar compared to Golamunda cluster was due to congenial 
atmospheric condition with moderate temperature throughout the year. In all the years, papaya yield was significantly lower in Kalahandi district compared to Dhenkanal district due to prevalence of high temperature and desiccating wind during summer months. Irrespective of the location, banana (bantala) productivity was significantly higher during 2010-11, which declined significantly during the next 2 years due to occurrence of disease in the subsequent years of planting. Among different clusters, Khajuripada attained the lowest fruit yield due to occurrence of diseases in the subsequent years. Dhenkanal Sadar cluster gave the maximum mean fruit yield of $36212 \mathrm{~kg} / \mathrm{ha}$, followed by Odapada with $33886 \mathrm{~kg} / \mathrm{ha}$ under the IFS model.

The drumstick yield increased significantly from year to year during the study period. Mean yield of $12675 \mathrm{~kg}$ was attained during 2010-11 and the yield increased by 33.7 and 46.5\% during 2011-12 and 2012-13 under IFS model when averaged over clusters. Among different clusters, significantly higher drumstick yield was attained in Dhenkanal Sadar cluster, closely followed by Odapada and Narla clusters due to better atmospheric condition for flowering and fruiting. Significantly lower drumstick yield was attained in Golamunda cluster.

The minimum poultry meat yield of $831.84 \mathrm{~kg}$ was attained during 2010-11 and the yield increased significantly by 1.4 and $4.1 \%$ during 2011-12 and 2012-13, respectively. The maximum mean meat yield of $878.3 \mathrm{~kg}$ was attained in Khajuripada cluster when averaged over years. The maximum productivity in Khajuripada cluster could be attributed to the congenial atmospheric conditions. The minimum yield in Odapada was due to high temperature condition prevailing in the cluster. The growth, food intake and physiological response were changed by the environmental temperature. The poultry birds are homeotherm animals which could live comfortably only in a relatively narrow zone of thermo neutrality. Both low and high temperatures are stressful and have negative effect on the economy of production and animal welfare (Yunianto et al., 1997). The meat yield declined by 1.9, 2.9, 4.0 and $8.9 \%$ in Narla, Golamunda, Dhenkanal Sadar and Odapada clusters, respectively. Mean poultry meat yield of $847.11 \mathrm{~kg} /$ annum was observed when averaged over the clusters and years.

Paddy straw mushroom was taken up in all the clusters for period of 8 months starting from April to March. The temperature condition for paddy straw mushroom was not congenial from November to February. The maximum of $944.9 \mathrm{~kg}$ paddy straw mushroom per annum was attained during 2012-13, while the minimum of $852.7 \mathrm{~kg}$ per annum was attained in 2011-12. Moderate production of $906.1 \mathrm{~kg}$ per annum was attained in 2010-11.

Among different clusters, Dhenkanal Sadar attained the maximum mushroom productivity of $1024.5 \mathrm{~kg}$ per annum, followed by Odapada cluster due to congenial temperature and relative humidity. Dhar et al., (2011) found an optimum temperature of $30-35^{0} \mathrm{C}$ as ideal for cultivation of paddy straw mushroom. Akinyele and Adetuyi (2005) found an appreciable mycelia growth of Volvariella volvacea between 25 and $40^{\circ} \mathrm{C}$ with highest mycelia dry weight (80 mg) obtained at $30^{\circ} \mathrm{C}$ and the least mycelia weight $(0.5 \mathrm{mg})$ was obtained at $10^{\circ} \mathrm{C}$. Two clusters of Kalahandi district viz. Narla and Golamunda attained low mushroom production of 804.5 and $824.9 \mathrm{~kg}$ per annum, respectively due to uncongenial weather conditions as compared to other clusters. Khajuripada cluster in Kandhamal district attained medium level mushroom productivity.

Oyster mushroom was taken up twice, once during November-December and again in 
January-February. The maximum of $729.3 \mathrm{~kg}$ per annum was obtained during 2012-13 and the minimum of $698.3 \mathrm{~kg}$ per annum during 2011-12. During 2010-11, moderate level mushroom production was attained with productivity of $715.7 \mathrm{~kg}$ per annum.

Dhenkanal Sadar cluster attained the maximum oyster mushroom production of $765.6 \mathrm{~kg}$ per annum, followed by Odapada with $757.2 \mathrm{~kg}$ per annum when averaged over years. Khajuripada cluster attained the minimum mushroom production of $672.7 \mathrm{~kg}$ per annum. The minimum fruiting body in Khajuripada cluster was due to chilling temperature that hindered the growth of fruiting bodies. Uddin et al., (2011) found a temperature regime $14-27^{\circ} \mathrm{C}$ with relative humidity of $70-80 \%$ to be favourable for cultivation of Pleurotus spp. Bano and Rajarathnam (1982) attained the maximum yield of oyster mushroom (Pleurotus sajorcaju) in the temperature range of $20-26^{\circ} \mathrm{C}$ and relative humidity of $70-90 \%$ and a fairly good yield was attained up to $30^{\circ} \mathrm{C}$. Thakur and Singh (2014) reported a temperature range of $20-28^{0} \mathrm{C}$ to be ideal for the growth of oyster mushroom. Golamunda and Narla clusters of Kalahandi district attained moderate mushroom production of 692.5 and $684.2 \mathrm{~kg}$ per annum (Table 10 and 11).

\section{Net returns from cropping}

Significantly higher net returns from rice was attained during 2012-13 both under IFS and rainfed farms (Table 3). Khajuripada cluster attained the minimum net returns due to the presence of low moisture retentive and percolating soil. All other clusters were found to be significantly superior to Khajuripada cluster in attaining net returns. Narla cluster attained the maximum net return of Rs. $24132 /$ ha in IFS farm when averaged over years. This was due to the presence of moisture retentive black soil. All other clusters were inferior to Narla cluster for the net returns. Khajuripada, Dhenkanal Sadar, Odapada and Golamunda clusters attained 58.7, 17.5, 27.8 and $38.2 \%$ lower net returns compared to Narla cluster.

The pond based IFS models and rainfed rice farms differed significantly for net returns. The rainfed rice farm over years gave net returns of Rs. 4981/ha. Irrigation with pond water enhanced the net returns by 2.5 times compared to rainfed rice farm. In rainfed rice farm, growth and yield of rice was affected due to the irregularities of weather. Being a shallow rooted crop, rice was highly susceptible to drought and supplemental irrigation through pond favoured growth and development and gave the maximum yield and net returns.

The net returns from onion were the highest during 2012-13 and were significantly higher compared to 2011-12 and 2010-11. Narla cluster gave net returns of Rs. 83,442/ha, followed by Golamunda cluster with Rs. 81,446 /ha which were at par with Narla when averaged over years. This was due to higher productivity in these two clusters and due to presence of black cotton soil which was quite congenial for the growth of the crop. Khajuripada cluster gave the lowest net returns due to the lowest yield as a result of presence of eroded and low fertile soil. Khajuripada, Dhenkanal Sadar and Odapada attained lower net returns of 27.8, 15.6 and $17.5 \%$ compared to Narla cluster.

The net returns from green gram was the maximum during 2012-13, while net returns during 2010-11 and 2011-12 were at par. During all the years, Dhenkanal district attained higher net returns than Kalahandi district from green gram. Dhenkanal Sadar cluster attained higher net returns than Odapada cluster due to higher productivity as a result of congenial soil conditions and Narla cluster attained higher net returns than 
Golamunda cluster. Golamunda gave the lowest net returns due to significantly lower yield.

\section{Net returns from non-crop enterprises}

The net returns from fish was the minimum of ₹ 51,219/ha during 2010-11, and it increased by 18.2 and $103.3 \%$ in 2011-12 and 2012-13, respectively (Table 4). Dhenkanal Sadar cluster attained the maximum mean net returns of ₹ 96,425/ha over years, which was at par with Odapada due to availability of optimum depth of water and congenial thermal environment for the growth of fish throughout the growth period. The net returns declined by 30.7, 41.6 and $47.9 \%$ in Narla, Golamunda and Khajuripada clusters, respectively. The lowest net returns was attained in Khajuripada cluster due to low fish yield as a result of low temperature during winter inhibiting the fish growth severely.

Among different years, the maximum net returns of ₹ 3,14,813/ha from papaya was attained in 2011-12. During 2010-11 and 201213, 71.7 and $35.1 \%$ less net returns was obtained. Among different clusters, Dhenkanal Sadar gave the maximum net returns of ₹ $2,48,969 /$ ha due to more congenial atmospheric conditions for flowering and fruiting. Odapada and Narla ranked the $2^{\text {nd }}$ and the $3^{\text {rd }}$ for net returns. Golamunda cluster recorded the minimum net returns from the crop due to more desiccating atmospheric conditions.

The net returns from banana showed an increasing trend over years. The net returns of ₹ 2,22,136/ha was attained in 2010-11 and the value increased by 36.5 and $80.1 \%$ in 2011-12 and 2012-13 under the IFS model. The mean net returns of ₹ 3,08,491/ha was attained from 1.6 ha model. Among different clusters, Dhenkanal Sadar ranked the first for net returns. Being a long duration crop, the performance depended on overall climatic conditions during the year. Odapada and Narla clusters ranked the $2^{\text {nd }}$ and the $3^{\text {rd }}$ for net returns. Khajuripada cluster recorded the minimum net returns from banana due to low productivity as a result of poor soil quality in the embankment.

The net returns from drumstick indicated a significant increase over years with the maximum of ₹ 4,82,250/ha during 2012-13. Over years, Dhenkanal Sadar cluster gave the maximum net returns of ₹ 3,74,700/ha in the model, followed by Odapada cluster. This was due to favorable weather conditions in these two clusters compared to Narla and Khajuripada. Narla and Khajuripada clusters ranked the $3^{\text {rd }}$ and the $4^{\text {th }}$ for net returns, while Golamunda cluster attained the lowest net returns from drumstick.

Among different years, 2011-12 gave the maximum annual net returns of ₹ 12,014 from poultry followed by ₹ 10,834 during 2012-13 and ₹ 7894 during 2010-11. Golamunda was the best with mean net returns of ₹ 11,730, followed by Narla cluster when averaged over years. This can be attributed to relatively dry weather which inhibited the incidence of diseases. Odapada cluster gave the minimum annual net returns of ₹ 8103 due to prevalence of warm humid weather, followed by Khajuripada cluster due to chilling weather temperature in December that inhibited growth and gave less meat yield.

Paddy straw mushroom was raised for 8 batches during March to October @ one batch per month. Oyster mushroom was raised for two batches during November-December and January-February, because optimum temperature was 25 to $38^{0} \mathrm{C}$ for paddy straw mushroom and 20 to $30^{\circ} \mathrm{C}$ for oyster mushroom.

Among three years, 2012-13 gave the maximum net returns of ₹ 30,349 from paddy 
straw mushroom. The annual net returns decreased by $₹ 8278(27.3 \%)$ and $₹ 8438$ (27.8\%) during 2010-11 and 2011-12, respectively. Dhenkanal Sadar was the most congenial for paddy straw mushroom production with annual net returns of ₹ 33,396/shed, while the cluster located in high altitude zone was the least remunerative with annual net return of ₹ 15,986/shed when averaged over years, because of the prevalence of low temperature in majority periods of the study period. The cluster is located at an altitude of 476 meter and atmospheric temperature was less than the clusters located in Dhenkanal and Kalahandi districts. The annual net returns declined by $14.3,28.5,34.1$ and $52.1 \%$ in Odapada, Golamunda, Narla and Khajuripada clusters compared to Dhenkanal Sadar cluster.

In case of oyster mushroom production, the net returns was the lowest of ₹ 17,727 during 2010-11 and it increased by 33.0 and $72.7 \%$ during 2011-12 and 2012-13, respectively. Golamunda was the most remunerative with total net returns of ₹ 28,379 which was at par with Narla with net returns of ₹ 27,870 when averaged over years. Due to higher price of the produce in these two clusters, net returns were higher. Khajuripada cluster gave the lowest net returns due to low production and extremely low temperature during the period. Dhenkanal Sadar, Odapada and Khajuripada had lower net returns by $11.4,13.0$ and $51.5 \%$, respectively over Golamunda.

\section{System productivity, profitability and employment generation}

Both main and interaction effects of sources of water and years on yield and monetary returns were statistically significant. Conventional rice-green gram system in the 1.6 ha farm gave rice equivalent yield (REY) of 4188 $\mathrm{kg} / \mathrm{ha}$ (Table 5). The pond based 1.6 ha IFS model farm increased the productivity by 5.7 times and proved significantly superior. The farming system constituting crop + dairy + poultry + fishery resulted in the highest system productivity of $1237.5 \mathrm{q}$ REY/ha, which was $1331.6 \%$ higher than the traditional (rice-wheat) cropping sequence. This could be attributed to better management, inclusion of profitable enterprises and efficient recycling of resources from one system to another, which reduced the total input requirement, lowering the cost of production (Singh et al., 2007). Gill et al., (2009) reported that diversification of farming system by integration of enterprises in varied farming situations of the country enabled to enhance the total production in terms of rice equivalent yield ranging from $9.2 \%$ in Eastern Himalayan region to as high as $366 \%$ in Western-plain and Ghat region when compared to prevailing farming systems of the region.

Rice Equivalent Yield (REY) was significantly lower of $15088 \mathrm{~kg} / \mathrm{ha}$ during 2010-11. There was a significant increase in REY over years with the maximum of 17238 $\mathrm{kg} / \mathrm{ha}$ attained during 2012-13. The pond based 1.6 ha IFS farm gave maximum REY of $30206 \mathrm{~kg} / \mathrm{ha}$ during 2012-13. The rainfed farm of 1.6 ha size incurred an expenditure of ₹ $36,996 / \mathrm{ha}$. The value increased significantly to ₹ $1,71,250 / \mathrm{ha}$ in the IFS model (3.6 times increase). The minimum cost of cultivation of ₹ 97,644/ha was attained during 2010-11.

There was a significant hike in the cost of cultivation during 2011-12 and 2012-13 with the maximum value of ₹ $1,11,441 / \mathrm{ha}$. The cost of cultivation under the pond based IFS model was the maximum of $₹ 1,83,252$ /ha during 2012-13. Both the two previous years recorded significantly less cost of cultivation.

The net returns from rice-green gram system was the minimum of $₹ 9522 /$ ha. The net returns increased significantly to ₹ $1,42,201 /$ ha in the pond based IFS model (13.9 times hike). 
Table.1 Productivity of crops $(\mathrm{kg} / \mathrm{ha})$ in 1.6 ha IFS model and rainfed farms in different clusters

\begin{tabular}{|c|c|c|c|c|c|c|}
\hline \multirow[t]{2}{*}{ Years/ Clusters } & \multicolumn{3}{|c|}{ Integrated farming system } & \multicolumn{3}{|c|}{ Conventional cropping system } \\
\hline & $\begin{array}{c}\text { Grain } \\
\text { yield of } \\
\text { rice }\end{array}$ & $\begin{array}{c}\text { Straw } \\
\text { yield of } \\
\text { rice }\end{array}$ & $\begin{array}{c}\text { Onion bulb } \\
\text { yield }\end{array}$ & $\begin{array}{c}\text { Grain yield } \\
\text { of rice }\end{array}$ & $\begin{array}{c}\text { Straw yield of } \\
\text { rice }\end{array}$ & $\begin{array}{l}\text { Grain yield of } \\
\text { green gram }\end{array}$ \\
\hline \multicolumn{7}{|c|}{ Years } \\
\hline 2010-11 & $3641 c$ & $3962 c$ & $20496 c$ & $2719 a$ & $3069 a$ & $494 a$ \\
\hline 2011-12 & $3816 b$ & $4137 b$ & $20881 b$ & $2606 b$ & $2938 b$ & $438 b$ \\
\hline 2012-13 & $4004 a$ & $4347 \mathrm{a}$ & $21125 a$ & $2706 a$ & $3056 a$ & $469 a$ \\
\hline Mean & 3816 & 4151 & 20832 & 2681 & 3025 & 469 \\
\hline $\operatorname{SEm}( \pm)$ & 28 & 42 & 70 & 19 & 25 & 6 \\
\hline LSD $(\mathbf{p}<0.05)$ & 49 & 70 & 119 & 38 & 38 & 25 \\
\hline \multicolumn{7}{|c|}{ Clusters } \\
\hline Khajuripada & $3166 \mathrm{e}$ & $3431 \mathrm{e}$ & $18791 \mathrm{e}$ & $2475 d$ & $2800 d$ & 0 \\
\hline $\begin{array}{l}\text { Dhenkanal } \\
\text { Sadar }\end{array}$ & $4046 b$ & $4382 b$ & $20482 c$ & $2825 a$ & $3181 \mathrm{a}$ & $538 \mathrm{a}$ \\
\hline Odapada & $3843 c$ & $4165 c$ & 20161d & $2613 c$ & $2944 c$ & $475 b$ \\
\hline Golamunda & $3655 d$ & $3955 d$ & $22243 b$ & $2675 b$ & $3019 b$ & $400 c$ \\
\hline Narla & $4382 a$ & $4801 \mathrm{a}$ & $22481 a$ & $2806 a$ & $3169 a$ & $450 \mathrm{~b}$ \\
\hline $\operatorname{SEm}( \pm)$ & 42 & 49 & 91 & 25 & 38 & 19 \\
\hline LSD $(p<0.05)$ & 63 & 84 & 147 & 44 & 50 & 25 \\
\hline
\end{tabular}

Values of years or clusters with same letter $(a, b, c, \ldots .$.$) are at par with each other$

Table.2 Productivity of non-crop enterprises in 1.6 ha IFS model

\begin{tabular}{|c|c|c|c|c|c|c|c|}
\hline \multirow[t]{2}{*}{ Years/ Clusters } & \multicolumn{4}{|c|}{ Yield from pond unit } & \multirow{2}{*}{$\begin{array}{c}\text { Meat } \\
\text { yield of } \\
\text { poultry } \\
\text { (kg/year) }\end{array}$} & \multicolumn{2}{|c|}{ Mushroom yield (kg/year) } \\
\hline & $\begin{array}{c}\text { Fish } \\
\text { (kg/ha) }\end{array}$ & $\begin{array}{l}\text { Fruit of } \\
\text { papaya } \\
\text { (kg/ha) }\end{array}$ & $\begin{array}{l}\text { Fruit of } \\
\text { banana } \\
\text { (kg/ha) }\end{array}$ & $\begin{array}{c}\text { Fruit of } \\
\text { drumstick } \\
\text { (kg/ha) }\end{array}$ & & Paddy straw & Oyster \\
\hline \multicolumn{8}{|c|}{ Years } \\
\hline 2010-11 & $2907 a$ & $59125 b$ & $33528 \mathrm{a}$ & $12675 \mathrm{c}$ & $831.84 c$ & $906.1 \mathrm{~b}$ & $715.7 \mathrm{~b}$ \\
\hline 2011-12 & $2637 \mathrm{c}$ & $79625 a$ & $32275 b$ & $16950 \mathrm{~b}$ & $843.42 \mathrm{a}$ & $852.7 \mathrm{c}$ & $698.3 \mathrm{c}$ \\
\hline 2012-13 & $2774 b$ & $47188 \mathrm{c}$ & $31112 c$ & $18575 \mathrm{a}$ & $866.08 \mathrm{a}$ & $944.9 \mathrm{a}$ & $729.3 a$ \\
\hline Mean & 2773 & 61969 & 32305 & 16050 & 847.11 & 901.2 & 714.4 \\
\hline $\operatorname{SEm}( \pm)$ & 18 & 1719 & 537 & 450 & 1.85 & 9.7 & 4.6 \\
\hline LSD $(p<0.05)$ & 29 & 2844 & 895 & 750 & $\mathbf{3 . 0 3}$ & 15.9 & 7.6 \\
\hline \multicolumn{8}{|c|}{ Clusters } \\
\hline Khajuripada & $2724 b$ & $57813 c$ & 28099d & $14650 \mathrm{c}$ & $878.3 \mathrm{a}$ & $885.4 \mathrm{c}$ & $672.7 \mathrm{c}$ \\
\hline $\begin{array}{c}\text { Dhenkanal } \\
\text { Sadar }\end{array}$ & $2884 a$ & $71094 a$ & $36212 \mathrm{a}$ & $17875 a$ & $842.9 d$ & $1024.5 \mathrm{a}$ & $765.6 \mathrm{a}$ \\
\hline Odapada & $2861 \mathrm{a}$ & $65875 b$ & $33886 b$ & $17225 \mathrm{ab}$ & $800.2 \mathrm{e}$ & $966.8 \mathrm{~b}$ & $757.2 \mathrm{a}$ \\
\hline Golamunda & $2634 c$ & $52313 d$ & 29471c & $13650 \mathrm{~d}$ & $853.0 \mathrm{c}$ & $824.9 d$ & $692.5 b$ \\
\hline Narla & $2761 b$ & $62750 \mathrm{~b}$ & $33796 b$ & $16875 b$ & $861.2 b$ & $804.5 \mathrm{~d}$ & $684.2 \mathrm{~b}$ \\
\hline SEm $( \pm)$ & 23 & 2250 & 716 & 600 & 2.40 & 12.5 & 6.0 \\
\hline LSD $(p<0.05)$ & 37 & 3656 & 1163 & 975 & 3.92 & 20.5 & 9.8 \\
\hline
\end{tabular}

Values of years or clusters with same letter $(a, b, c, \ldots .$.$) are at par with each other$ 
Table.3 Net returns (₹/ha)) from cropping in 1.6 ha IFS model and rainfed farms in different clusters

\begin{tabular}{|c|c|c|c|c|}
\hline \multirow[t]{2}{*}{ Years/ Clusters } & \multicolumn{2}{|c|}{ Integrated farming system } & \multicolumn{2}{|c|}{ Conventional cropping system } \\
\hline & Rice & Onion & Rice & Green gram \\
\hline \multicolumn{5}{|c|}{ Years } \\
\hline 2010-11 & $13357 \mathrm{c}$ & $46253 c$ & $4643 b$ & $4934 b$ \\
\hline 2011-12 & $15291 b$ & $66131 b$ & $2964 c$ & $4070 b$ \\
\hline 2012-13 & $23164 a$ & $106259 a$ & $7338 \mathrm{a}$ & $8023 a$ \\
\hline Mean & 17270 & 72881 & 4981 & 5676 \\
\hline $\operatorname{SEm}( \pm)$ & 648 & 1633 & 264 & 771 \\
\hline LSD $(\mathbf{p}<0.05)$ & 1059 & 2669 & 432 & 1260 \\
\hline \multicolumn{5}{|c|}{ Clusters } \\
\hline Khajuripada & $9973 \mathrm{e}$ & $60262 c$ & $3274 d$ & 0 \\
\hline Dhenkanal Sadar & $19918 b$ & $70415 b$ & $6453 a$ & $8040 a$ \\
\hline Odapada & $17421 \mathrm{c}$ & $68838 b$ & $3832 d$ & $5842 b$ \\
\hline Golamunda & 14910d & $81446 a$ & $4949 c$ & $3641 c$ \\
\hline Narla & $24132 \mathrm{a}$ & $83442 a$ & $6399 b$ & $5181 b c$ \\
\hline $\operatorname{SEm}( \pm)$ & 837 & 2108 & 341 & 995 \\
\hline LSD $(p<0.05)$ & 1367 & 3446 & 558 & 1626 \\
\hline
\end{tabular}

Values of years or clusters with same letter $(a, b, c, \ldots .$.$) are at par with each other$

Table.4 Net returns (₹/ha) from non-crop enterprises

\begin{tabular}{|c|c|c|c|c|c|c|c|}
\hline \multirow{2}{*}{$\begin{array}{c}\text { Years/ } \\
\text { Clusters }\end{array}$} & \multicolumn{4}{|c|}{ Pond unit } & \multirow{2}{*}{$\begin{array}{l}\text { Poultry } \\
\text { unit }\end{array}$} & \multicolumn{2}{|c|}{ Mushroom unit } \\
\hline & Fish & Papaya & Banana & Drumstick & & $\begin{array}{l}\text { Paddy } \\
\text { straw }\end{array}$ & Oyster \\
\hline \multicolumn{8}{|c|}{ Years } \\
\hline 2010-11 & $51719 b$ & $89000 c$ & $222136 c$ & $170300 \mathrm{c}$ & $7894 c$ & $22071 \mathrm{c}$ & $17727 \mathrm{c}$ \\
\hline 2011-12 & $61144 b$ & $314813 a$ & $303152 b$ & $330000 \mathrm{~b}$ & $12014 a$ & $21911 \mathrm{c}$ & $23572 b$ \\
\hline 2012-13 & $105163 a$ & $204375 b$ & $400155 a$ & $482250 a$ & $10834 b$ & $30349 a$ & $30608 \mathrm{a}$ \\
\hline Mean & 72675 & 202719 & 308491 & 327525 & 10248 & 24778 & 23969 \\
\hline $\operatorname{SEm}( \pm)$ & 7044 & 12781 & 7935 & 14100 & 427 & 1622 & 399 \\
\hline LSD $(p<0.05)$ & 11513 & 20875 & 12946 & 23075 & 698 & 2649 & 651 \\
\hline \multicolumn{8}{|c|}{ Clusters } \\
\hline Khajuripada & $50238 \mathrm{c}$ & $180531 c$ & $257782 \mathrm{c}$ & $327525 b$ & $9042 b$ & $15986 d$ & $13756 \mathrm{c}$ \\
\hline $\begin{array}{c}\text { Dhenkanal } \\
\text { Sadar }\end{array}$ & $96425 a$ & $248969 a$ & $355561 \mathrm{a}$ & $374700 \mathrm{a}$ & $11035 a$ & $33396 a$ & $25144 b$ \\
\hline Odapada & $93681 \mathrm{a}$ & 224281ab & $329341 b$ & $354350 \mathrm{ab}$ & $8103 c$ & $28626 b$ & $24696 b$ \\
\hline Golamunda & $56263 b c$ & $152125 d$ & $272189 c$ & $268625 c$ & $11730 a$ & $23876 c$ & $28379 a$ \\
\hline Narla & $66769 b$ & $207656 b$ & $327253 b$ & $346775 \mathrm{ab}$ & $11328 \mathrm{a}$ & $22007 c$ & $27870 a$ \\
\hline $\operatorname{SEm}( \pm)$ & 9094 & 16531 & 10261 & 18250 & 551 & 2094 & 515 \\
\hline LSD $(p<0.05)$ & 14856 & 26969 & 16734 & 29775 & 902 & 3420 & 840 \\
\hline
\end{tabular}

Values of years or clusters with same letter $(a, b, c, \ldots .$.$) are at par with each other$ 
Table.5 Effect of source of water (S) and year (Y) on productivity and economics

\begin{tabular}{|c|c|c|c|c|c|c|c|c|}
\hline Source & 2010- & 2011-12 & $\begin{array}{c}2012- \\
13\end{array}$ & Mean & $\begin{array}{c}2010- \\
11\end{array}$ & ${ }_{12}^{2011-}$ & $2012-$ & Mean \\
\hline & \multicolumn{4}{|c|}{ Rice equivalent yield (kg/ha) } & \multicolumn{4}{|c|}{ Cost of cultivation ( $₹ / h a$ ) } \\
\hline No pond & 4281 & 4013 & 4269 & 4188 & 34215 & 37144 & 39629 & 36996 \\
\hline Pond & 25888 & 28150 & 30206 & 28081 & 161072 & 169427 & 183252 & $\begin{array}{c}17125 \\
0\end{array}$ \\
\hline Mean & 15088 & 16081 & 17238 & 16131 & 97644 & 103286 & 111441 & $\begin{array}{c}10412 \\
3\end{array}$ \\
\hline LSD (S) & 475 & & & & 2149 & & & \\
\hline LSD (Y) & 581 & & & & 2633 & & & \\
\hline LSD $(\mathbf{S} \times \mathbf{Y})$ & 819 & & & & 3723 & & & \\
\hline \multirow[t]{2}{*}{$\begin{array}{c}\text { Pond : No } \\
\text { pond }\end{array}$} & 6.05 & 7.02 & 7.08 & 6.71 & 4.71 & 4.56 & 4.62 & 4.63 \\
\hline & \multicolumn{4}{|c|}{ Net returns $(₹ / \mathrm{ha})$} & \multicolumn{4}{|c|}{ Benefit-cost ratio } \\
\hline No pond & 8589 & 6220 & 13756 & 9522 & 1.24 & 1.16 & 1.34 & 1.25 \\
\hline Pond & 97834 & 134549 & 194221 & $\begin{array}{c}14220 \\
1\end{array}$ & 1.61 & 1.79 & 2.06 & 1.82 \\
\hline Mean & 53211 & 70385 & 103989 & 75862 & 1.54 & 1.68 & 1.93 & 1.73 \\
\hline LSD (S) & 7398 & & & & 0.03 & & & \\
\hline LSD (Y) & 9061 & & & & 0.03 & & & \\
\hline $\operatorname{LSD}(\mathbf{S} \times \mathbf{Y})$ & 12814 & & & & 0.04 & & & \\
\hline \multirow[t]{2}{*}{$\begin{array}{l}\text { Pond : No } \\
\text { pond }\end{array}$} & 11.39 & 21.63 & 14.12 & 14.93 & 1.30 & 1.54 & 1.54 & 1.46 \\
\hline & \multicolumn{4}{|c|}{$\begin{array}{l}\text { Labour employment (human } \\
\text { days/ha/year) }\end{array}$} & & & & \\
\hline No pond & 236 & 236 & 238 & 236 & & & & \\
\hline Pond & 591 & 588 & 589 & 590 & & & & \\
\hline Mean & 413 & 413 & 414 & 413 & & & & \\
\hline LSD (S) & 12 & & & & & & & \\
\hline LSD (Y) & NS & & & & & & & \\
\hline LSD $(\mathbf{S} \times \mathbf{Y})$ & NS & & & & & & & \\
\hline $\begin{array}{l}\text { Pond : No } \\
\text { pond }\end{array}$ & 2.51 & 2.49 & 2.48 & 2.50 & & & & \\
\hline
\end{tabular}

Values of years or clusters with same letter $(a, b, c, \ldots .$.$) are at par with each other$ 
Table.6 Rice equivalent yield (REY) and economics of farms in different clusters

\begin{tabular}{|c|c|c|c|c|c|}
\hline Clusters & REY (kg/ha) & $\begin{array}{c}\text { Cost of } \\
\text { production } \\
(₹ / h a)\end{array}$ & $\begin{array}{l}\text { Net returns } \\
(₹ / h a)\end{array}$ & $\begin{array}{c}\text { Benefit-cost } \\
\text { ratio }\end{array}$ & $\begin{array}{c}\text { Labour } \\
\text { employment } \\
\text { (human } \\
\text { days/ha/year) }\end{array}$ \\
\hline Khajuripada & $13788 \mathrm{c}$ & $98641 b$ & $55167 b$ & $1.56 \mathrm{c}$ & $378 b$ \\
\hline $\begin{array}{c}\text { Dhenkanal } \\
\text { Sadar }\end{array}$ & $17038 \mathrm{ab}$ & $105784 a$ & $84357 a$ & $1.80 \mathrm{a}$ & $423 a$ \\
\hline Odapada & $16350 b$ & $105606 a$ & 76807a & $1.73 b$ & $423 a$ \\
\hline Golamunda & $16381 \mathrm{ab}$ & $105389 a$ & $77318 \mathrm{a}$ & $1.73 b$ & $419 a$ \\
\hline Narla & $17119 a$ & $105196 a$ & $85659 a$ & $1.81 \mathrm{a}$ & $421 \mathrm{a}$ \\
\hline SEm ( $( \pm)$ & 356 & 1629 & 5608 & 0.02 & 9 \\
\hline LSD $(p<0.05)$ & $\mathbf{7 5 0}$ & 3399 & 11697 & 0.04 & 19 \\
\hline
\end{tabular}

Values of years or clusters with same letter $(a, b, c, \ldots .$.$) are at par with each other$

Table.7 Recyclable wastes in pond based integrated farming system model

\begin{tabular}{|c|c|c|c|}
\hline Treatments & Pond silt (kg) & Poultry excreta (kg) & $\begin{array}{c}\text { Mushroom spent } \\
\text { (kg) }\end{array}$ \\
\hline \multicolumn{4}{|l|}{ Years } \\
\hline 2010-11 & 5000 & 2031c & $13020.6 b$ \\
\hline 2011-12 & 5000 & $2091 b$ & $12944.0 c$ \\
\hline 2012-13 & 5000 & 2191a & $13102.7 \mathrm{a}$ \\
\hline Mean & 5000 & 2104 & 13022.4 \\
\hline $\operatorname{SEm}( \pm)$ & & 6 & 17 \\
\hline LSD $(p<0.05)$ & NS & 9 & 28 \\
\hline \multicolumn{4}{|l|}{ Clusters } \\
\hline Khajuripada & 5000 & $2183 a$ & $13042.5 a$ \\
\hline Dhenkanal Sadar & 5000 & 2094d & $13057.0 \mathrm{a}$ \\
\hline Odapada & 5000 & 1987 e & $13075.5 a$ \\
\hline Golamunda & 5000 & $2119 c$ & $12964.7 b$ \\
\hline Narla & 5000 & $2139 b$ & $12972.5 b$ \\
\hline $\operatorname{SEm}( \pm)$ & & 7 & 23 \\
\hline LSD $(p<0.05)$ & NS & 12 & 37 \\
\hline
\end{tabular}

Values of years or clusters with same letter $(a, b, c, \ldots .$.$) are at par with each other$ 
Table.8 Sustainable Yield Index (SYI) and Sustainable Value Index (SVI) as influenced by cluster and source of water in 1.6 ha IFS model

\begin{tabular}{|c|c|c|c|c|}
\hline \multirow{2}{*}{ Clusters } & \multicolumn{2}{|c|}{ SYI } & \multicolumn{2}{c|}{ SVI } \\
\cline { 2 - 5 } Khajuripada & No pond & Pond & No pond & Pond \\
\hline Dhenkanal Sadar & 0.08 & 0.73 & 0.01 & 0.31 \\
\hline Odapada & 0.15 & 0.85 & 0.04 & 0.48 \\
\hline Golamunda & 0.13 & 0.82 & 0.02 & 0.46 \\
\hline Narla & 0.14 & 0.83 & 0.03 & 0.52 \\
\hline Mean & $\mathbf{0 . 1 3}$ & 0.87 & 0.03 & $\mathbf{0 . 4 4}$ \\
\hline
\end{tabular}

Table.9 Chemical properties of soil of IFS models

\begin{tabular}{|c|c|c|c|c|c|c|}
\hline Clusters & Texture & pH & $\begin{array}{c}\text { Organic } \\
\text { carbon }(\%)\end{array}$ & $\begin{array}{c}\mathrm{N} \\
(\mathrm{kg} / \mathrm{ha})\end{array}$ & $\begin{array}{c}\mathbf{P} \\
(\mathrm{kg} / \mathrm{ha})\end{array}$ & $\begin{array}{c}\mathrm{K} \\
(\mathrm{kg} / \mathrm{ha})\end{array}$ \\
\hline \multicolumn{7}{|c|}{ At start of experiment } \\
\hline Khajuripada & Sandy clay loam & 5.8 & $0.42(\mathrm{~L})$ & $218.0(\mathrm{~L})$ & $21.0(\mathrm{M})$ & $143.0(\mathrm{M})$ \\
\hline $\begin{array}{c}\text { Dhenkanal } \\
\text { Sadar }\end{array}$ & Clay loam & 7.4 & $0.66(\mathrm{M})$ & 209.0(L) & $8.9(\mathrm{~L})$ & $144.5(\mathrm{M})$ \\
\hline Odapada & Clay loam & 6.6 & $0.86(\mathrm{H})$ & $241.0(\mathrm{~L})$ & $6.4(\mathrm{~L})$ & $241.0(\mathrm{M})$ \\
\hline Golamunda & Clay & 6.8 & $0.45(\mathrm{~L})$ & $188.0(\mathrm{~L})$ & $22.8(\mathrm{M})$ & $236.5(\mathrm{M})$ \\
\hline Narla & Clay & 7.6 & $0.84(\mathrm{H})$ & $239.6(\mathrm{~L})$ & $16.8(\mathrm{M})$ & $317.0(\mathrm{H})$ \\
\hline \multicolumn{7}{|c|}{ At end of experiment } \\
\hline Khajuripada & Sandy clay loam & 6.1 & $0.68(\mathrm{M})$ & 218.3(L) & $24.2(\mathrm{M})$ & $161.2(\mathrm{M})$ \\
\hline $\begin{array}{c}\text { Dhenkanal } \\
\text { Sadar }\end{array}$ & Clay loam & 7.5 & $0.79(\mathrm{H})$ & $224.0(\mathrm{~L})$ & $10.7(\mathrm{~L})$ & $161.6(\mathrm{M})$ \\
\hline Odapada & Clay loam & 6.9 & $0.98(\mathrm{H})$ & 248.3(L) & $9.5(\mathrm{~L})$ & 260.3(M) \\
\hline Golamunda & Clay & 6.9 & $0.68(\mathrm{M})$ & $235.6(\mathrm{~L})$ & 24.6(M) & 258.8(M) \\
\hline Narla & Clay & 7.5 & $0.95(\mathrm{H})$ & 244.2(L) & $19.3(\mathrm{M})$ & $329.3(\mathrm{H})$ \\
\hline
\end{tabular}


Table.10 Monthly rainfall ( $\mathrm{mm})$ in different clusters

\begin{tabular}{|c|c|c|c|c|c|c|c|c|c|c|c|c|c|}
\hline $\begin{array}{l}\text { Month / } \\
\text { Clusters }\end{array}$ & Apr & May & Jun & Jul & $\begin{array}{c}\mathrm{Au} \\
\mathrm{g}\end{array}$ & Sep & Oct & Nov & Dec & Jan & Feb & Mar & Total \\
\hline \multicolumn{14}{|c|}{$2010-11$} \\
\hline Kpd & 20 & 138 & 144 & 299 & 246 & 265 & 79 & 24 & 38 & 0 & 9 & 12 & 1274 \\
\hline Dsr & 0 & 196 & 195 & 211 & 260 & 186 & 114 & 14 & 42 & 0 & 62 & 0 & 1280 \\
\hline Opd & 0 & $\begin{array}{c}116 . \\
9\end{array}$ & 202 & 321.5 & $\begin{array}{c}199 \\
.5\end{array}$ & 222 & 206 & 8 & 63 & 0 & 62 & 2 & 1402.9 \\
\hline Gmd & 16 & 78 & 33 & 152 & 211 & 173 & 47 & 0 & 20 & 0 & 0 & 0 & 730 \\
\hline Nrl & 0 & 25 & 94 & 403 & 251 & 198.5 & 138.5 & 0 & 41 & 0 & 3 & 0 & 1154 \\
\hline \multicolumn{14}{|c|}{ 2011-12 } \\
\hline Kpd & 101 & 92 & 206 & 109 & 460 & 339.6 & 35 & 0 & 0 & 110 & 0 & 0 & 1452.6 \\
\hline Dsr & 55 & 164 & 355 & 135 & 468 & 431 & 0 & 0 & 0 & 115 & 0 & 0 & 1723 \\
\hline Opd & 19 & 91 & 203 & 133.5 & 367 & 392 & 5 & 0 & 0 & 96 & 0 & 0 & 1306.5 \\
\hline Gmd & 23 & 14 & 86 & 51 & 120 & 99 & 0 & 0 & 0 & 0 & 0 & 0 & 393 \\
\hline Nrl & 18 & 24.5 & 170 & 217 & 371 & 263.5 & 18 & 0 & 0 & 24 & 2 & 2 & 1110 \\
\hline \multicolumn{14}{|c|}{ 2012-13 } \\
\hline Kpd & 87 & 19 & 130 & 366 & 278 & 244.9 & 85.5 & 75 & 0 & 0 & 5.0 & 0 & 1290.4 \\
\hline Dsr & 28 & 70 & $\begin{array}{c}108 . \\
5\end{array}$ & 431 & 387 & 282.5 & 131 & 102 & 0 & 0 & 0 & 0 & 1539.5 \\
\hline Opd & 7 & 45 & $\begin{array}{c}241 . \\
5\end{array}$ & 304 & 360 & 355 & 38 & 86.5 & 0 & 0 & 0 & 0 & 1435.0 \\
\hline Gmd & 2 & 0 & 69 & 98 & 185 & 113 & 14 & 5 & 0 & 0 & 4 & 0 & 490.0 \\
\hline Nrl & 28 & 2 & 174 & 195 & 314 & 372 & 21 & 13 & 0 & 2.0 & 10 & 0 & 1131.0 \\
\hline
\end{tabular}

Table.11 Monthly average maximum and minimum temperature $\left({ }^{0} \mathrm{C}\right)$ in different districts

\begin{tabular}{|c|c|c|c|c|c|c|}
\hline \multirow{2}{*}{ Months } & \multicolumn{2}{|c|}{ Kandhamal } & \multicolumn{2}{c|}{ Dhenkanal } & \multicolumn{2}{c|}{ Kalahandi } \\
\cline { 2 - 7 } & Maximum & Minimum & Maximum & Minimum & Maximum & Minimum \\
\hline Apr & 37.9 & 20.6 & 37.7 & 23.3 & 40.2 & 24.4 \\
\hline May & 39.0 & 23.6 & 39.7 & 24.4 & 41.2 & 26.6 \\
\hline Jun & 32.3 & 22.8 & 37.9 & 24.3 & 37.7 & 26.5 \\
\hline Jul & 29.8 & 22.1 & 33.4 & 23.0 & 31.7 & 24.6 \\
\hline Aug & 29.6 & 21.9 & 32.7 & 24.1 & 31.6 & 24.1 \\
\hline Sep & 26.7 & 20.9 & 32.3 & 23.4 & 31.0 & 23.5 \\
\hline Oct & 30.1 & 15.0 & 32.9 & 20.7 & 28.8 & 20.0 \\
\hline Nov & 28.9 & 13.9 & 30.3 & 16.9 & 31.0 & 16.7 \\
\hline Dec & 26.8 & 8.5 & 27.6 & 14.8 & 29.0 & 12.0 \\
\hline Jan & 27.4 & 9.1 & 31.2 & 15.4 & 29.3 & 12.8 \\
\hline Feb & 30.6 & 11.1 & 31.6 & 16.1 & 32.4 & 15.3 \\
\hline Mar & 35.4 & 14.4 & 34.6 & 18.7 & 37.2 & 19.8 \\
\hline
\end{tabular}


Fig.1 Resource recycling in 1.6 ha IFS model with crop+ fish+ poultry+ mushroom integration

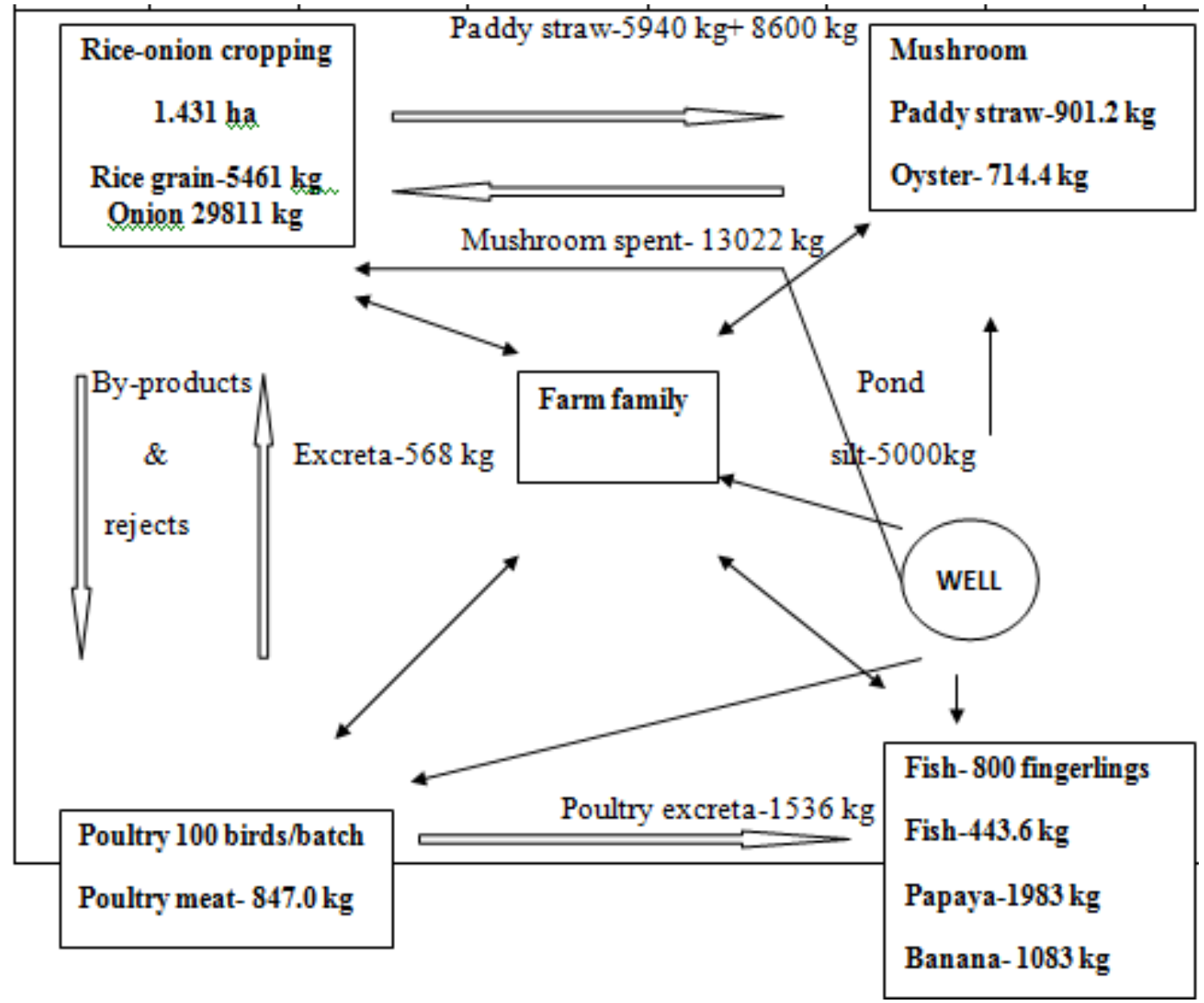

The net returns was the minimum of ₹53,211/ha during 2010-11. The value increased significantly by 32.3 and $95.4 \%$, respectively during 2011-12 and 2012-13 over 2010-11. The pond based model gave the maximum net returns of ₹ 1,94,221/ha during 2012-13. All other combinations of sources of water and years recorded significantly lower net returns.

The value of benefit-cost ratio was the lowest of 1.25 with conventional rice-green gram system. The value increased significantly to 1.82 in the pond based IFS model farm. The ratio was the minimum of 1.54 during 201011. The ratio showed significant increase each year reaching the maximum value of 1.93 during 2012-13. The pond based IFS model during 2012-13 gave the maximum BC ratio of 2.06. All other combinations attained significantly lower $\mathrm{BC}$ ratio.

The conventional rice-green gram system required 236 human days/ha/year. Employment opportunities increased significantly due to diversifying rice farm to IFS model. Employment opportunities in IFS model was 590 human days/ha/year (1.5 times increase). Employment opportunities did not differ significantly over years. The interaction effect of sources of water and years was found non-significant.

The economic output from different enterprises was expressed as rice equivalent yield. Narla cluster recorded the maximum system productivity with REY of $17119 \mathrm{~kg} / \mathrm{ha}$ (Table 6). Dhenkanal Sadar and Golamunda 
remained at par with Narla cluster. This was due to better soil resources for land based enterprise i.e., cropping and more congenial climate for pisciculture, poultry and mushroom. Khajuripada cluster proved least productive with REY of $13788 \mathrm{~kg} / \mathrm{ha}$ and remained significantly inferior to all other clusters. The minimum cost of cultivation of ₹98,641/ha was attained in Khajuripada cluster. Significant increase in cost of cultivation was attained in the other four clusters.

The system profitability was the minimum in Khajuripada cluster. The maximum profitability was attained in Narla cluster with ₹ 85,659/ha followed by Dhenkanal Sadar with ₹ 84,357/ha. Ravisankar et al., (2007) reported a lower cost of production with better productivity of each component integrated in the system. Das et al., (2013) realized 284 and $176 \%$ higher system net returns through pig and duck based multiple use of pond water through diversified farming (crop, fruit, livestock and fishery) than the farmers' practice (without integration) respectively. Narla cluster attained highest BC ratio of 1.81 and Dhenkanal Sadar remained at par with it. Khajuripada cluster attained the minimum BC ratio of 1.56 and was significantly inferior to all other clusters.

The employment opportunities were the highest of 423/ha/year in Dhenkanal Sadar and Odapada clusters. Except Khajuripada, all other clusters had at par labour employment as Dhenkanal Sadar. Khajuripada cluster attained the minimum labour employment of 378/ha/year which was significantly lower than other clusters. The farming system involving cropping, fishery, piggery, dairy and duckery attained the maximum number of man days/ha/year (890). Generation of additional employment opportunities under farming system approach was due to the diversification and integration of crops, livestock, fishery and horticulture (Rathore and Bhatt, 2008). Ghosh et al., (2009) and Das et al., (2013) observed an enhancement in cropping intensity, employment generation and farm income owing to rainwater harvesting and its efficient recycling in farm ponds.

\section{Recyclable resources}

After harvest of fish every year, $5000 \mathrm{~kg}$ of pond silt was lifted from the pond of 1.6 ha IFS model (Table 7). The silt deposited in the pond came to the pond by erosion from embankment and also from surrounding fields and excreta and feed applied to pond. Desilting was done during May after drying of the pond to maintain depth of water level in the pond for pisciculture. The silt was used in crop fields for improving the soil health. Jeyamangalam et al., (2012) reported a decrease in bulk density due to increase in the doses of tank silt. During 2010-11, farmers reared 5 batches of broiler birds. Annual excreta production was the minimum of 2031 $\mathrm{kg}$ during 2010-11. The excreta production increased significantly during 2011-12 and 2012-13 with the maximum of $2191 \mathrm{~kg}$ during 2012-13. Among clusters, the annual production of poultry excreta was the maximum of $2183 \mathrm{~kg}$ in Khajuripada cluster which was significantly higher than other clusters. Excreta production decreased by 2.0, 2.9, 4.1 and 9.0\% in Narla, Golamunda, Dhenkanal Sadar and Odapada clusters, respectively. The maximum excreta yield could be attributed to maximum consumption of feed and conversion to body weight and excreta.

Among different years, the mean mushroom spent production was the lowest of $12944 \mathrm{~kg}$ per shed during 2011-12 and the maximum value was $13102.7 \mathrm{~kg}$ during 2012-13. Mushroom spent was the minimum of 12964.7 $\mathrm{kg}$ in Golamunda to the maximum of 13075.5 $\mathrm{kg}$ in Odapada cluster when averaged over years. Dhenkanal Sadar and Khajuripada 
remained at par with Odapada. Golamunda and Narla recorded significantly less mushroom spent production. The low variability among clusters was due to use of equal quantity of straw and inputs as per recommendation in all the clusters. The quantity of straw used per shed was $1440 \mathrm{~kg}$ per batch for paddy straw mushroom and $562.5 \mathrm{~kg}$ per batch per shed for oyster mushroom. The quantum of mushroom spent straw was higher than sum of straw and inputs because of addition of mycelia. Rangasamy (1999) reported that inclusion of mushroom enterprise as one of the components in IFS with the production capacity of $2 \mathrm{~kg} / \mathrm{day}$ utilized about $1800 \mathrm{~kg}$ paddy straw and could yield $2340 \mathrm{~kg}$ of spent mushroom substrate after the harvest of edible mushroom at the end of one year. The enhancement in the weight in the mushroom spent was due to unharvested mycelia growth. Averaged over years and clusters, the mean annual mushroom spent production was $13022 \mathrm{~kg}$ per shed.

\section{Resource recycling}

The 1.6 ha IFS model gave $5461 \mathrm{~kg}$ grain of rice, $29811 \mathrm{~kg}$ of onion, $443.6 \mathrm{~kg}$ fish, 1983 $\mathrm{kg}$ papaya, $1083 \mathrm{~kg}$ banana, $642 \mathrm{~kg}$ drumstick, $847 \mathrm{~kg}$ poultry meat, $901.2 \mathrm{~kg}$ paddy straw mushroom and $714.4 \mathrm{~kg}$ oyster mushroom for use by the farm family and recyclable wastes of $5940 \mathrm{~kg}$ paddy straw, $5000 \mathrm{~kg}$ pond silt, $2104.0 \mathrm{~kg}$ poultry excreta and $13022 \mathrm{~kg}$ mushroom spent for recycling in the system and use as input by other units (Fig. 1). The conventional cropping provided rice and green gram for consumption. Due to efficient recycling of resources, the productivity and profitability of IFS models were higher compared to conventional cropping system. Babalad and Hundekar (1999) reported that under integrated farming system, it might be possible to reach the same level of yield with proportionately less input and yield would be more sustainable because the waste material of one enterprise would become input of another, leaving almost no waste to pollute the environment or to degrade resource base.

In IFS, the farm is considered as independent unit, although several external factors influence the system. Recycling of resources between biotic and abiotic components through various bio-geo-chemical processes occurs in independent IFS units similarly as in larger ecosystems. The farming system through smaller unit, care is taken for recycling of the by-products from different enterprises. In our study, the cropping enterprise generated by-products like straw. Straw was utilized for mushroom production. The spent mushroom subsequently converted to compost and nutrient and carbonaceous materials were returned back to the crop field. Paddy straw was an ideal substrate for growth of mushroom. Chandrasekharan et al., (1994) reported that the quality of mushroom grown on paddy straw was superior to the mushroom grown in any other substrate. The poultry excreta amounting to $1536 \mathrm{~kg}$ was utilized in the fish pond for feeding to 800 poly culture fingerlings of IFS pond and surplus amount was utilized in the crop field. Application of these excreta favoured the growth of phytoplankton, the primary producer in this recycling process.

Ravishankar et al., (2007) found that the nutrient content of poultry manure increased manifolds after recycling into compost. The nutrients recycled from poultry and duckery were more in terms of plankton (256/litre) development in the ponds for fish growth. Phytoplankton subsequently boosted the growth of zooplankton which served as food for fishes. Several authors have reported the role of poultry manure in enhancing the production of phyto and zooplankton promoting growth of fish and ultimately giving higher fish productivity. Tank silt amounting to $5000 \mathrm{~kg}$ from the IFS model pond was desilted during summer after drying the 
pond and utilized in the crop field. The tank silt boosted the organic carbon and content of soil $\mathrm{N}, \mathrm{P}$ and $\mathrm{K}$ and improved soil health. The surplus quantity of poultry droppings was converted to manure. The nutrient content of the compost was enhanced by this conversion process. Application of poultry compost improved the soil health and gave higher yield. Jayanthi et al., (2003) reported that integration of poultry + fish + cropping nourished with recycled poultry manure sustained the productivity of soil through the addition of residue with better NPK nutrient supply potential $(88,20$ and $27 \mathrm{~kg}$ of NPK, respectively). Verma and Bhagat (1994) observed that plant growth parameters and yield contributing characters were affected positively by the incorporation of poultry manure and FYM and thus resulted in the highest grain and straw yield of rice.

Some external inputs like poultry feed and part of straw requirement of mushroom unit were procured from sources outside the system. The system provided food and nutritional security. The paddy straw was utilized for mushroom production. As the straw obtained from the IFS unit was not sufficient for year round production of mushroom, the extra straw was purchased from outside. The water from the well was utilized for family consumption, mushroom unit, poultry unit and for recharging the farm pond at the time of need. The broken grains and rice bran were fed to poultry birds and fish. In conventional cropping system, the crop residues, by-products and other wastes were not efficiently utilized.

\section{Sustainable yield index and sustainable value index}

The productivity of farming system in the absence of on-farm water harvesting pond was unsustainable as indicated by SYI values ranging from 0.08 in Khajuripada to 0.15 in Dhenkanal Sadar cluster under 1.6 ha model
(Table 8 ). The trend was more or less similar for SVI values also. The construction of onfarm water harvesting pond enhanced both SYI and SVI values. The SYI values increased to 0.73 in Khajuripada and 0.87 in Narla cluster in the 1.6 ha IFS model. Solaiappan et al., (2007) got high sustainability yield index for combination of enterprises compared to cropping alone for net returns. Similarly, the SVI values increased from 0.03 in conventional farm to 0.44 in the IFS model.

\section{Soil properties}

The value of $\mathrm{pH}$ remained either constant or increased marginally over initial values (Table 8). In Khajuripada cluster, $\mathrm{pH}$ was very low and the increase was significant. The increase of $\mathrm{pH}$ may be due to addition of organics which enhanced the buffering capacity of the soil. Nageswaran et al., (2009) compared various soil parameters in IFS and conventional farming and found the neutrality of $\mathrm{pH}$ in IFS. This was possibly due to intensive application of organic input while in conventional farming, there was building up of salt leading to alkalinity.

The organic carbon content increased due to implementation of IFS models in rice farms. This may be due to application of compost prepared from recyclable waste materials. The models having low initial carbon content exhibited medium organic content and plots having medium carbon content showed either medium or high carbon status at the end of the experiment. Sharanappa and Shivaraj(1995) reported that the organic carbon content of the soil increased due to addition of organic matter in the soil.

The content of $\mathrm{N}, \mathrm{P}$ and $\mathrm{K}$ increased substantially due to conversion of rice farm to IFS model. The increase in available N, P and $\mathrm{K}$ may be due to addition of organic matter in form of compost which released nutrients after 
decomposition and helped in dissolution of unavailable form of the nutrients in soil. Walia and Kaur (2013) reported that IFS plays an important role in improving the soil health by increasing the nutritional value of soil. The benefits of the use of livestock manure in crop production are improvements in soil physical properties and the provision of $\mathrm{N}, \mathrm{P}, \mathrm{K}$ and other mineral nutrients. Kaleeshwari (2001) reported that continuous incorporation of poultry manure increased the activity of phosphatase enzyme involved in hydrolytic cleavage of inorganic $\mathrm{P}$ that becomes available to the plants. The application of livestock manure increases soil organic matter content, and this leads to improved water infiltration and water holding capacity as well as an increased cation exchange capacity. Manure raised the $\mathrm{pH}$ level and accelerated the decomposition of organic matter (Brouwer and Powell, 1995; 1998).

Due to the effective recycling of organic residues and animal wastes from different IFS components, the soil fertility improved, with higher values of organic $\mathrm{C}$, soil $\mathrm{N}, \mathrm{P}$ and $\mathrm{K}$ nutrients of the fields with different IFS components compared with the crop cultivation alone (Solaiappan et al.,2007).

In rainfed areas, farmers should diversify compact patch of rice farm to multi-enterprise farming system models to achieve higher productivity and profitability on sustainable basis and ensure livelihood security of small farmers in rural areas. The 1.6 ha IFS model in rainfed tract of the state gave rice equivalent yield of $28081 \mathrm{~kg} / \mathrm{ha}$, net returns of ₹ $1,42,201 /$ ha and $\mathrm{BC}$ ratio of 1.82 compared to REY of $4188 \mathrm{~kg} / \mathrm{ha}$, net returns of ₹ 9522/ha and $\mathrm{BC}$ ratio of 1.25 in conventional ricegreen gram system. The IFS model provided $5461 \mathrm{~kg}$ grain of rice, $29811 \mathrm{~kg}$ of onion, $443.6 \mathrm{~kg}$ fish, $1983 \mathrm{~kg}$ papaya, $1083 \mathrm{~kg}$ banana, $642 \mathrm{~kg}$ drumstick, $847 \mathrm{~kg}$ poultry meat, $901.2 \mathrm{~kg}$ paddy straw mushroom and
$714.4 \mathrm{~kg}$ oyster mushroom to the farm family and recyclable by-products of $5940 \mathrm{~kg}$ paddy straw, $5000 \mathrm{~kg}$ tank silt, $2104 \mathrm{~kg}$ poultry excreta and $13022 \mathrm{~kg}$ mushroom spent for recycling in the system and use as input by other units. The SYI and SVI values were 0.82 and 0.44 respectively, in pond based model as compared to 0.13 and 0.03 in conventional cropping system.

\section{Acknowledgement}

The authors acknowledge the financial support received from Indian Council of Agricultural Research, New Delhi and World Bank through National Agricultural Innovation Project (Component-3) sub-project entitled 'Sustainable rural livelihood and food security to rainfed farmers of Odisha' and help received from farmers, Co-PIs, Associated Scientists and staff for execution of the study in various cluster of villages in different districts of Odisha, India. The authors acknowledge the administrative support provided by Odisha University of Agriculture and Technology, Bhubaneswar for smooth implementation of the project.

\section{References}

Akinyele, B.J. and Adetuyi, F.C. 2005. Effect of Agrowastes, $\mathrm{pH}$ and temperature variation on the growth of Volvariella volvacea. African Journal of Biotechnolog., 4 (12): 1390-1395.

Babalad, H.B. and Hundekar, S.T. 1999. Organic recycling of farm wastes in integrated farming systems for sustainable production. In: Lecture notes of summer short course on Farming Systems for Sustainable Production, 24 May-2 June, 1999. University of Agricultural Sciences, Dharwad. Pp. 150-165.

Bano, Z. and Rajarathnam, S. 1982. Studies on the cultivation of Pleurotus sajarcaju. 
Mushroom Journal. 115: 243-247.

Brouwer, J. and Powell, J.M. 1995. Soil aspects of nutrient cycling in a manure experiment in Niger. In: Powell, J.M., Fernandez-Rivera, S., Williams, T.O. and Renard, C. (Eds.). Livestock and sustainable nutrient cycling in mixed farming systems of sub-Saharan Africa. Vol II: Technical papers. Proceeding of International Conference, 22-26 November, 1993, Addis Ababa, Ethiopia. Pp. 211-226.

Brouwer, J. and Powell, J.M. 1998. Microtopography, water balance, millet yield and nutrient leaching in a manuring experiment on sandy soil in south-west Niger. In: Renard, G., Neef, A., Becker, K. and Von Oppen, M. (Eds).Soil fertility management in West African landuse systems. Proceeding of workshop, 4-8 March, 1997, Niamey, Margraf, Weikersheim. Pp. 349-360.

Chandrashekaran, B., Ramanathan, S.P. and Govindasamy, K.N. 1994. Rice based IFS approach in Cauvery delta region. Report on IFSR and Management in Sustainable Agriculture. Tamil Nadu Agricultural University, Coimbatore. Pp 258-293.

Das, A., Choudhury, B.U., Ramkrushna, G.I., Tripathi, A.K., Singh, R.K., Ngachan, S.V., Patel, D.P., Layek, J. and Munda, G.C. 2013. Multiple Use of Pond Water for Enhancing Water Productivity and Livelihood of Small and Marginal Farmers. Indian Journal of Hill Farming. 26 (1): 29-36.

Dhar, B.L., Shrivastava, N., Kumar, H.J., Tyagi, S. and Atrey, P. 2011. Cultivated Edible Speciality Mushrooms-Scope in India and EU Countries. Proceedings of $7^{\text {th }}$ International Conference on Mushroom Biology and Mushroom Products (ICMBMP7).
Directorate of Agriculture and Food production. 2014. Odisha Agriculture Statistics, 2012-13. Government of Odisha. 114 pages.

Ghosh, P.K., Saha R., Das, A., Tripathi, A.K., Samuel, M.P., Lama, T.D., Mandal, S. and Ngachan, S.V. 2009. Participatory Rain water Management in Hill Ecosystem - a success story. Technical Bulletin No. 67. FPARP- Phase I. ICAR Research Complex for NEH Region, Umiam-793 103, Meghalaya. Pp 37.

Gill, M.S., Singh, J.P. and Gangwar, K.S. 2009. Integrated farming system and agriculture sustainability. Indian Journal of Agronomy. 54 (2): 128-139.

Gomez, K.A. and Gomez, A.A. 1984. Statistical procedures for agricultural research. A Willey inter science publication, New York. Pp. 76-83.

Govindan, R., Chinnusamy, K.N., Chandrashekaran, B., Budhar, M.N. and Prince, J. 1990. Poultry- fish culture in rice farming system in Cauvery Delta region of Tamil Nadu. Indian Journal of Agronomy. 35: 2329.

Islam, M.D.J. and Mondal, M. K. 1992. Water management strategy for increasing monsoon rice production in Bangladesh. Agricultural Water Management. 22 (4): 335-343.

Jayanthi, C., Mythili, S., Balusamy, S., Sakthivel, N. and Sankaran, N. 2003. Integrated nutrient management through residue recycling in low land integrated farming systems. Madras Agricultural Journal. 90 (1-3): 103107.

Jeyamangalam, F., Annadurai, B. and Arunachalam, N. 2012. Effect of tank silt as organic ammendment on physical properties of Tehir soil using groundnut. Journal of Soils and Crops. 22 (1): 10-14. 
Kaleeshwari, R.K. 2001. Bio-organic influence of phosphatic fertilizer on phosphatase activity in wet land ecosystem. In: Abstracts of Agricultural Sciences Section, 3-7 January, 2001，88 ${ }^{\text {th }}$ Session of Indian Science Congress, New Delhi.

Kumar, K. and Ayyapan, S. 1998. Current Practises in Integrated Aquaculture. Integrated Aquaculture In Eastern India. Working paper 5.

Ministry of Agriculture, Government of India, 2015. Agricultural Statistics at a glance 2014. 452 pages.

Nageswaran, M., Selvaganapathy, E., Subbiah, V. R. and Nair, S. 2009. Comparison between demonstrated integrated farming system and farmers' conventional farming system. In: Demonstration and replication of integrated farming systems in Chidambaram. M.S. Swaminathan Research Foundation, Chennai. 78 pages.

Piper,C.S. 1950. Soil and plant analysis. University Adelaide, Australia. Pp. 368.

Rangasamy, A. 1999. Integrated Farming Systems for Sustainable Crop Production. In: Lecture notes on short course on Farming systems for Sustainable Production, 24th May - 2nd June, University of Agricultural Sciences, Dharwad. Pp.1-20.

Rathore, S.S. and Bhatt, B.P. 2008. Productivity improvement in jhum fields through integrated farming system. Indian Journal of Agronomy. 53(3): 167-171.

Ravishankar, N., Pramanik, S.C., Rai, R. B., Nawaz, S., Biswas, T. K. and Bibi, N. 2007. Study on integrated farming system in hilly upland areas of Bay islands. Indian Journal of Agronomy. 52(1): 7-10.

Sharanappa and Shivaraj, B. 1995. Influence of pre-season crops on productivity of rice-sunflower sequences and soil fertility status. Indian Journal of Agronomy. 40(4): 538-543.

Singh, K., Singh, A.K., Singh, K.K. and Singh, C.S. 2004. Analysis of farming systems in north eastern plain zone of Uttar Pradesh. Journal of Farming Systems Research and Development. 10 (1-2): 1-6.

Singh, K., Bohra, J.S., Singh, T.K., Singh, J.P., Singh, Y. and Singh, C.S. 2007. Productivity and economics of integrated farming system in irrigated agroecosystem of eastern Uttar Pradesh. Indian Journal of Agronomy. 52 (1): 1115.

Solaiappan, U., Subramanian, V. and Maruthi Sankar, G. R. 2007. Selection of suitable integrated farming system model for rainfed semi-arid vertic inceptisols in Tamil Nadu. Indian Journal of Agronomy. 52(3): 194-197.

Thakur, M.P. and Singh, H.K. 2014. Advances in the cultivation technology of tropical mushrooms in India JNKVV Research Journal. 48(2) : 120-135.

Uddin, M.N., Yesmin, S., Khan, M.A., Tania, M., Moonmoon, M. and Ahmed, S. 2011. Production of oyster mushrooms in different seasonal conditions of Bangladesh. Journal of Scientific Research. 3(1): 161-167.

Verma, T.S. and Bhagat, R.M. 1994. Effect of organic amendments on electrochemical and chemical kinetics and growth and yield of rice. Oryza. 31(3): 206-212.

Walia, S.S. and Kaur, N. 2013. Integrated Farming System - An Eco-friendly Approach for Sustainable Agricultural Environment - A Review. Greener Journal of Agronomy, Forestry and Horticulture. 1(1): 1-11.

Yashouv, A. 1963. Increasing fish production in ponds. In: Symposium on fishery 
problems in Europe. Transaction of The American Fisheries Society. 92(3): 291-292.

Yunianto, B.V.D., Hayashi, K., Kaneda, S., Ohtuska, A and Tomita, Y. 1997.
Effect of environmental temperature on muscle protein turnover and heat production in tube-fed broiler chickens. British Journal of Nutrition. 77: 897-909.

\section{How to cite this article:}

Hemanta Kumar Sahoo, Basudev Behera, Manoranjan Satapathy and Stuti Debapriya Behera. 2019. Sustainable Rural Livelihood Security of Small Farmers through Efficient Resource Recycling in Crop-Fish-Poultry-Mushroom based Integrated Farming System Model. Int.J.Curr.Microbiol.App.Sci. 8(12): 1745-1768. doi: https://doi.org/10.20546/ijcmas.2019.812.210 